\title{
RAILWAY FINANCING VIA URBAN DEVELOPMENT
}

\author{
ELIFF CAN CENGİZ \& HÜSEYIN MURAT ÇELIKK \\ Istanbul Technical University, Turkey
}

\begin{abstract}
Railway projects are extremely expensive and long-lasting investments. Most countries are facing difficulties funding these projects from their national budget. Such projects clearly have an impact on land use and land value. Literature shows that property and land values increase after a transport investment is made in a particular corridor. Rail system projects have the highest impact on property values, because they increase accessibility to urban areas. Rail system projects are becoming very popular in Turkey, especially in Istanbul, one of the most important and most populated cities in Turkey. Existing road, sea and rail transport systems are not sufficient to meet the demand for mobility in the city. Since urban public transport systems rarely make a profit, they do not attract private investors. Furthermore, it is not possible to pay for all rail system investments from public funds. This paper aims to develop a new model for the financing of rail systems in Turkey. The main aim is to calculate with a Hedonic Pricing model the impact of the proximity of a property to a station of a rail system on the value of that property, and then to reflect this impact on a proposed rail system project in Istanbul. In the Hedonic Pricing model, properties are characterized by their composite attributes, thus the value of a property can be calculated by adding up the estimated value of all its separate attributes. This model makes it possible to calculate the impact of each and every attribute of a property on its value. In this study the distance to a metro station is the primary attribute with other structural features also affecting property value. The model is run with 11 attributes. As a result of this model a coefficient can be calculated that relates to the impact of distance to a station on the value of the property. As a further research, recommendations will be developed to use this calculated value in the financing of railway project.
\end{abstract}

Keywords: transportation, railway, railway financing, hedonic pricing model, Istanbul.

\section{INTRODUCTION}

Transport infrastructure investments have a long-run impact on the economic, social and physical structure of cities. This is especially true for public transport investments such as rail transit and bus transit investments. Rail systems have fixed infrastructures which lead to permanent and radical changes in urban areas. The fixed infrastructure also makes rail transit project extremely expensive [1].

As it is stated by Jain [2], demand for high quality and efficient transport networks as well as its related infrastructure, both at national and international level, is increasing. Despite the increasing demand, the capability of economies to meet this demand is insufficient due to issues like limited investment funds, unpredictable revenues, political interventions and lack of technical know-how.

Transport is one of the most important services in urban areas. It has a direct impact on urban development and urban macroform. The proximity to a main transport facility has a direct impact on the value of the land in that particular urban area. Especially the rail transit modes are very crucial for the pattern of urban development. Studies reveal that rail transit operations have a positive impact on urban areas such as increasing accessibility as a result of transport investments which results in less time lost in urban traffic [3].

In this study, the asserted problem and its potential solution is investigated together. The indicated problem mainly refers to the limited funding resources for railway transit investments and the potential for increasing land values through transport investments. The main intention of this study is to exhibit the calculations reflecting the impact of transport 
investments on land values and to propose a kind of preliminary baseline in using these figures in potential railway financing.

\section{LITERATURE REVIEW}

After the year 2000 Turkey focused on railway investments on both urban and national scale. Current development plans of Turkey include further network extensions, increasing rail patronage and further improvement and modernization of the railway sector.

For most of the public transport systems a substantial amount of subsidies from the government is required for their construction, maintenance and operation. The question is, where this money will come from [4].

There are many different funding mechanisms to support transit operations. Governments and local authorities are trying to meet the mobility needs of communities by imposing different policies to collect money. These can be either property-based, or based on taxes, charges and fees.

According to Nakagava and Matsunaka [5], in theory the most basic concept of financial resources is that "those who enjoy the benefits of transport improvements should bear the corresponding costs." But it is not a simple task to define the beneficiaries.

Nakagava and Matsunaka [5] argue that it is very difficult to identify benefits derived from any transport investment. Thus it is important to simplify the method. During this study benefits are estimated by determining the change of real estate value by using the Hedonic Pricing model. The model will be developed on an existing railway corridor, then the calculated value of the railway's impact on the housing market will be applied on a proposed railway project.

In literature an often discussed option for financing is "value capture".

It is known that public transport has a positive impact on property and land prices. The study attempts to demonstrate this.

According to Salon [4]: "Successful public transport systems generate substantial economic value for cities because they improve accessibility in station areas." They increase the value of the land in the areas around stations and they support the "agglomeration economies" that make cities the vibrant engines of our global economy." Value capture is a concept that allows governments to utilize some parts of the value generated from public transport investments and use them for financing its construction, maintenance and operation. According to Nakagava and Matsunaka [5], in the transportation market; when new roadways/railways are implemented, the value of the surrounding land increases, but without special funding systems being in place the landowners will be reluctant to meet the cost of construction. Turkey has a growing economy and thus needs more investment in every sector across the country. All these projects are in macro scale and are expensive projects. The national economy is not capable of maintaining all these projects simultaneously. As a general policy of the current government both national and international private investors are encouraged to invest in these mega projects.

All of these projects are very expensive and sound investments. The Turkish economy may not possess a suitable financial infrastructure to implement several projects at the same time within a given period of time. Furthermore, these projects require highly qualified producers. At present the workforce and know-how of the Turkish public sector is not sufficient to realize these investments. That is why the public sector utilizes the private sector's know-how and funds. In Turkey the public sector stands only as a controller and monitoring mechanism in Public Private Partnership (PPP) projects.

In Turkey such PPP projects generally use the Built Operate Transfer (BOT) Model. The private sector constructs operates for a given period of time and transfers the property to the 
public sector after the operation period comes to an end. However, economic instability does not attract private investors, especially foreign investors to undertake mega projects in this country. Thus in order to encourage the private sector, the government gives generous guarantees to them. For instance; for the EUROASIA Tunnel the Ministry guaranteed 25 million crossings per year, that is 68,000 vehicles per day, and any excess revenue will be paid to the Treasury by the contractor. However, by 22/01/2017 the average number of vehicles crossing the tunnel per day was between 20,000-25,000. The crossing fee is $4 \$+\mathrm{VAT}$, and the Treasury has to pay the fees of the remaining number of vehicles per day to the contractor [6].

All these PPP projects in Turkey are planned on the basis of operation revenue. Transport projects are all national scale projects and very popular. They are estimated to generate sufficient revenue for the private sector, with the government giving the guarantee to meet the delta between investment cost and operation revenue, should the operational revenue fall short. This study looks at the possibility of relieving the government of having to provide guarantees to the private sector for the realization of these projects.

\subsection{Case study selection and introduction}

Istanbul has a population of 14,657,434 and a land area of 5,313 square kilometers. $18 \%$ of the total population of Turkey lives in Istanbul. This makes Istanbul the most populated city in Turkey. Istanbul is also vibrant in terms of economic activities. Production, labor, business, import-export activities are mainly concentrated in Istanbul. This high population and economic activity creates high mobility needs. There are many diversified modal split options in the city including sea, rail and road transportation.

Istanbul has been investing in public transport systems, especially rail systems, since the 1980s. However, the coverage of the urban rail system is insufficient at present. Although constantly expanding, progress is slow due to the construction time and cost involved. Istanbul consists of two parts, one in Asia and the other in Europe. The Bosporus that runs in between has always formed an obstacle to the creation of an integrated rail transport network. Both sides have constructed transport networks that are disconnected from each other. As a result the share of daily rail trips within Istanbul is relatively low. It was only at the end of 2013 that the two separate rail networks were connected via Railway Bosphorus Tube Crossing (Marmaray).

There are 11 different rail lines in Istanbul including heavy rail, light rail, tramway and funicular. The total length of the rail networks in Istanbul is $133 \mathrm{~km}$. If we consider the linear macroform of the city this is not enough. Only central areas benefit from the rail systems. Peripheral areas mostly depend on transport by bus or minibus. Istanbul has a very challenging geography, thus it is very expensive to implement rail systems in every part of the city. Although the rail systems in Istanbul serve a limited area, daily ridership is relatively high, with the average daily ridership on the total Istanbul rail network being 1,400,000 in 2014 [7]. Since 2004 there has been an improvement in the rail network and today the total length of the network has reached $145.45 \mathrm{~km}$. Between 2016 and 2019 the construction of $322.41 \mathrm{~km}$ of new rail lines is planned in Istanbul. Some projects will be completed in 2024 at which point the total rail network will be $1000.15 \mathrm{~km}$.

There are more than 60 projects planned or ongoing in Istanbul. One of these is selected for the case study. In order to narrow down the number of projects, commuter rail lines, monorail, telpher lines, and tramway projects were eliminated, only metro projects were left, as literature suggests that when compared to metro lines their impact on urban land value is relatively lower. Metro lines have the highest impact on land value, thus in this study metro 
Table 1: Total population served by railway projects.

\begin{tabular}{|c|c|c|c|c|c|}
\hline & $\begin{array}{l}\text { Railway projects to be } \\
\text { completed between } 2019 \text { - } \\
2024\end{array}$ & \multirow{3}{*}{$\frac{\text { Length }(\mathrm{km})}{20}$} & \multirow[b]{2}{*}{ Districts } & \multirow[b]{2}{*}{ Population } \\
\hline & & Line & & & \\
\hline 1 & 2016 & \multirow{3}{*}{$\begin{array}{l}\text { Üsküdar-Ümraniye- } \\
\text { Çekmeköy-Sancaktepe }\end{array}$} & & Üsküdar & 540,617 \\
\hline & & & & Ümraniye & 688,347 \\
\hline & & & & Çekmeköy & 231,818 \\
\hline & & & & TOTAL & $1,815,664$ \\
\hline \multirow[t]{4}{*}{2} & 2019 & \multirow{3}{*}{$\begin{array}{l}\text { Dudullu-Kayişdaği- } \\
\text { İçerenköy-Bostanci }\end{array}$} & 14.3 & Kadiköy & 465,954 \\
\hline & & & & Ataşehir & 419,368 \\
\hline & & & & Ümraniye & 688,347 \\
\hline & & & & TOTAL & $2,255,405$ \\
\hline 3 & 2018 & Altunizade-Çamlica & 14.3 & Üsküdar & 540,617 \\
\hline \multirow[t]{6}{*}{4} & 2019 & \multirow{5}{*}{$\begin{array}{l}\text { Ataköy-Basin } \\
\text { Ekspres-İkitelli }\end{array}$} & 13 & Bakirköy & 223,248 \\
\hline & & & & Bahçelievler & 602,040 \\
\hline & & & & Bağcilar & 757,162 \\
\hline & & & & Küçükçekmece & 761,064 \\
\hline & & & & Başakşehir & 353,311 \\
\hline & & & & TOTAL & $3,237,442$ \\
\hline \multirow[t]{4}{*}{5} & 2019 & Göztepe-Ataşehir-Ümraniye & 13 & Kadiköy & 465,954 \\
\hline & & & & Ataşehir & 419,368 \\
\hline & & & & Ümraniye & 688,347 \\
\hline & & & & TOTAL & $1,573,669$ \\
\hline \multirow[t]{5}{*}{6} & 2019 & \multirow{4}{*}{$\begin{array}{l}\text { Mahmutbey-Halkali- } \\
\text { Bahçeşehir-Esenyurt Tem }\end{array}$} & 16.24 & Bağcilar & 757,162 \\
\hline & & & & Küçükçekmece & 761,064 \\
\hline & & & & Avcilar & 425,228 \\
\hline & & & & Esenyurt & 742,810 \\
\hline & & & & TOTAL & $2,686,264$ \\
\hline \multirow[t]{3}{*}{7} & 2019 & Yenikapi-İncirli-Sefaköy & 14 & Fatih & 419,345 \\
\hline & & & & Zeytinburnu & 289,685 \\
\hline & & & & TOTAL & 709,030 \\
\hline \multirow{4}{*}{8} & \multirow{3}{*}{$\begin{array}{l}\text { after } \\
2019\end{array}$} & \multirow{3}{*}{\begin{tabular}{|l} 
Sefaköy-Avcilar \\
Esenyurtbeylikdüzü \\
Büyükçekmece Tüyap \\
\end{tabular}} & 18 & Bakirköy & 223,248 \\
\hline & & & & Bahçelievler & 602,040 \\
\hline & & & & Küçükçekmece & 761,064 \\
\hline & & & & TOTAL & $1,586,352$ \\
\hline \multirow{5}{*}{9} & \multirow{3}{*}{$\begin{array}{l}\text { after } \\
2019\end{array}$} & Vezneciler-Sultangazi & 18.1 & Fatih & 419,345 \\
\hline & & & & Eyüp & 375,409 \\
\hline & & & & Gaziosmanpaşa & 501,546 \\
\hline & & & & Sultangazi & 521,524 \\
\hline & & & & TOTAL & $1,817,824$ \\
\hline
\end{tabular}

lines are selected and on the basis of some principles one case study is chosen. Banister et al. [8] claim that the impact on property value depends on the scale of investment. Small scale investments improve the accessibility of a location, whereas large scale investments also have an impact on the property market. By 2024 a total of 33 metro projects will be realized in Istanbul, providing a total metro line of $338,74 \mathrm{~km} \mathrm{[7].}$ 
At present a large number of projects are being constructed in Istanbul. In order to select a case study certain limitations were introduced. It is very hard to assess an increase in property value along a long corridor, thus the corridor length was limited to a route length of $20 \mathrm{~km}$. Short corridors were also eliminated from the project sample because they are not adequate to show the value changes. The sample that is selected needed to have an adequate length and number of stations. In short, only projects between 10 to $20 \mathrm{~km}$ lengths were examined in order to select a case study.

Projects according to their length are shown in the figure above. 9 projects have a length between $10 \mathrm{~km}-20 \mathrm{~km}$. In 2016 the total railway network of Istanbul was $145.45 \mathrm{~km}$. A new filtering criteria was needed to select one case study for this study. Ridership is another variable that makes public transport systems effective, thus it is important to consider potential ridership of these projects. There are 39 districts in Istanbul, 25 of them are on the European side and 14 on the Anatolian side. Depending on the length of the metro line these corridors pass through more than one district. In order to forecast potential ridership; the districts and their total population also have to be taken into account.

Table 1 above shows all districts where each line is passing through. The number of districts would be more meaningful when their population is taken into consideration. In the table below population of districts is shown.

As some routes are longer than others and pass through more districts, the population served along one $\mathrm{km}$ of the line is a more meaningful variable for case study selection than the total population of the districts.

The Ataköy-Basın Ekspres-İkitelli Line (Item 4 above) has the highest potential ridership, item 3 has the lowest. This project (Project number 3 ) is eliminated from the selection as it has the lowest average "population served" ratio. Ridership numbers are very much related to proximity to alternative transport means in the area. While keeping in mind these population figures, the proximity to other transport modes is considered in the following part of the study.

Table 2: Average population served by rail system projects.

\begin{tabular}{|r|c|l|c|c|c|}
\hline \multicolumn{2}{|c|}{} & \multicolumn{1}{|c|}{ Line } & $\begin{array}{c}\text { Length } \\
\mathbf{( k m )}\end{array}$ & $\begin{array}{c}\text { Total population } \\
\text { served }\end{array}$ & $\begin{array}{c}\text { Average } \\
\text { population served }\end{array}$ \\
\hline 1 & 2016 & $\begin{array}{l}\text { Üsküdar-Ümraniye- } \\
\text { Çekmeköy-Sancaktepe }\end{array}$ & $\mathbf{2 0}$ & $\mathbf{1 , 8 1 5 , 6 6 4}$ & $\mathbf{9 0 , 7 8 3}$ \\
\hline 2 & 2019 & $\begin{array}{l}\text { Dudullu-Kayişdaği- } \\
\text { İçerenköy-Bostanci }\end{array}$ & $\mathbf{1 4 . 3}$ & $\mathbf{1 , 5 7 3 , 6 6 9}$ & $\mathbf{1 1 0 , 0 4 7}$ \\
\hline 3 & 2018 & Altunizade-Çamlica & $\mathbf{1 4 . 3}$ & 540,617 & $\mathbf{3 7 . 8 0 5}$ \\
\hline 4 & 2019 & $\begin{array}{l}\text { Ataköy-Basin Ekspres- } \\
\text { İkitelli }\end{array}$ & $\mathbf{1 3}$ & $\mathbf{3 , 2 3 7 , 4 4 2}$ & $\mathbf{2 4 9 . 0 3 4}$ \\
\hline 5 & 2019 & Göztepe-Ataşehir-Ümraniye & $\mathbf{1 3}$ & $\mathbf{1 , 5 7 3 , 6 6 9}$ & $\mathbf{1 2 1 , 0 5 1}$ \\
\hline 6 & 2019 & $\begin{array}{l}\text { Mahmutbey-Halkali- } \\
\text { Bahçeşehir-Esenyurt Tem }\end{array}$ & $\mathbf{1 6 . 2 4}$ & $\mathbf{2 , 6 8 6 , 2 6 4}$ & $\mathbf{1 6 5 , 4 1 0}$ \\
\hline 7 & 2019 & Yenikapi-İncirli-Sefaköy & $\mathbf{1 4}$ & $\mathbf{7 0 9 , 0 3 0}$ & $\mathbf{5 0 , 6 4 5}$ \\
\hline 8 & $\begin{array}{l}\text { after } \\
2019\end{array}$ & $\begin{array}{l}\text { Sefaköy-Avcilar } \\
\text { Esenyurtbeylikdüzü } \\
\text { Büyükçekmece Tüyap }\end{array}$ & $\mathbf{1 8}$ & $\mathbf{1 , 5 8 6 , 3 5 2}$ & $\mathbf{8 8 , 1 3 1}$ \\
\hline 9 & $\begin{array}{l}\text { after } \\
2019\end{array}$ & $\begin{array}{l}\text { Vezneciler-Sultangazi } \\
\mathbf{1 8 . 1}\end{array}$ & $\mathbf{1 , 8 1 7 , 8 2 4}$ & $\mathbf{1 0 0 , 4 3 2}$ \\
\hline
\end{tabular}




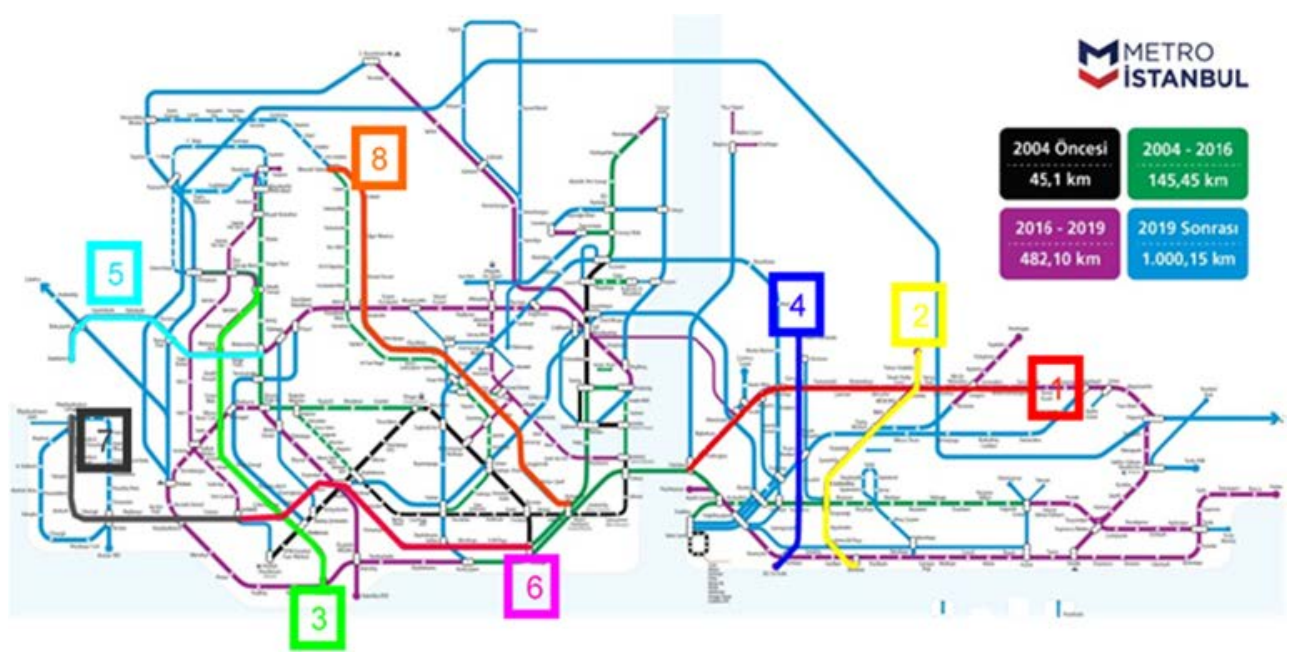

Figure 1: Potential case studies on the whole of the rail network in Istanbul [7].

Table 3: List of potential case studies.

\begin{tabular}{|c|c|c|c|}
\hline & & LINE & LENGTH (KM) \\
\hline 1 & 2016 & Üsküdar-Ümraniye-Çekmeköy-Sancaktepe & 20 \\
\hline 2 & 2019 & Dudullu-Kayişdaği-İçerenköy-Bostanci & 14.3 \\
\hline 3 & 2019 & Ataköy-Basin Ekspres-İkitelli & 13 \\
\hline 4 & 2019 & Göztepe-Ataşehir-Ümraniye & 13 \\
\hline 5 & 2019 & Mahmutbey-Halkali-Bahçeşehir-Esenyurt Tem & 16.24 \\
\hline 6 & 2019 & Yenikapi-İncirli-Sefaköy & 14 \\
\hline 7 & $\begin{array}{l}\text { after } \\
2019 \\
\end{array}$ & $\begin{array}{l}\text { Sefaköy-Avcilar Esenyurtbeylikdüzü } \\
\text { Büyükçekmece Tüyap }\end{array}$ & 18 \\
\hline 8 & $\begin{array}{l}\text { after } \\
2019\end{array}$ & Vezneciler-Sultangazi & 18.1 \\
\hline
\end{tabular}

Figures for planned rail networks in 2024 are shown in Table 2. These projects are examined with regard to their location and proximity to other transport options.

Each Istanbul metro line planned for 2024 is color coded in Fig. 1.

Project number 3 is regarded suitable for the case study since it has the optimal length for a metro infrastructure. After it is completed it is going to serve one of the most important corridors in Istanbul between two main motorway axles, the D-100and TEM motorways. Besides the districts it will also serve the existing Atatürk Airport. After the New Third Airport is completed the land on which Atatürk Airport is located, could become an important land for development. In the light of the above data, project number 3 - the AtaköyBasinekspres-İkitelli Metro Line on the European side is selected as the main case study.

\section{METHODOLOGY}

As it is suggested by various studies, the distance from a transport infrastructure is one of the most important variables that affect property value. Many authors calculated the optimal distance from origin to station as ranging between 400 meters to 2000 meters [8] According 
to Turkish legislation 500 meters is regarded as a reasonable walking distance. This is defined by the average walking distance to primary schools, kindergartens and basic health facilities. Thus real estate data is collected within a 500 meter radius from stations.

The primary aim of this study is to calculate the impact of metro stations on property values in the surrounding area within a 500 meter radius. The impact of proximity to metro stations is calculated using the Hedonic Pricing model. This model allows calculating the impact of each and every attribute on property values, including location, structural and neighborhood variables.

According to Herath and Maier [9] the idea behind the Hedonic Pricing model is as follows: properties are characterized by their composite attributes; thus the value of a property can be calculated by adding up the estimated values of all its separate attributes. Those attributes can be listed as number of rooms, size and age of the property, proximity to certain uses etc.

The construction of the project, which is selected based on data on Table 1 and Table 2. It is shown in Fig. 1 project number 3, has just commenced. Thus at present there is no operating station that can be used in the model. In order to calculate the impact of the rail system station on surrounding property values a secondrailway corridor is selected to develop the Hedonic Pricing model which is an extension railway corridor called Esenler-Kirazl Metro Line. The new case study corridor is selected according to its location which is very close to the main case study area. Istanbul is an unique city with complicated dynamics. Those two case studies were selected because they are very close to each other. Both corridors have similar features such as land use around the stations, and they have similar socioeconomic, cultural and income features.

The sample data for this study comes from on-site surveys carried out by the survey teams consisting of 4-5 graduate students and real estate agents working together in a 500 meters circular zones.

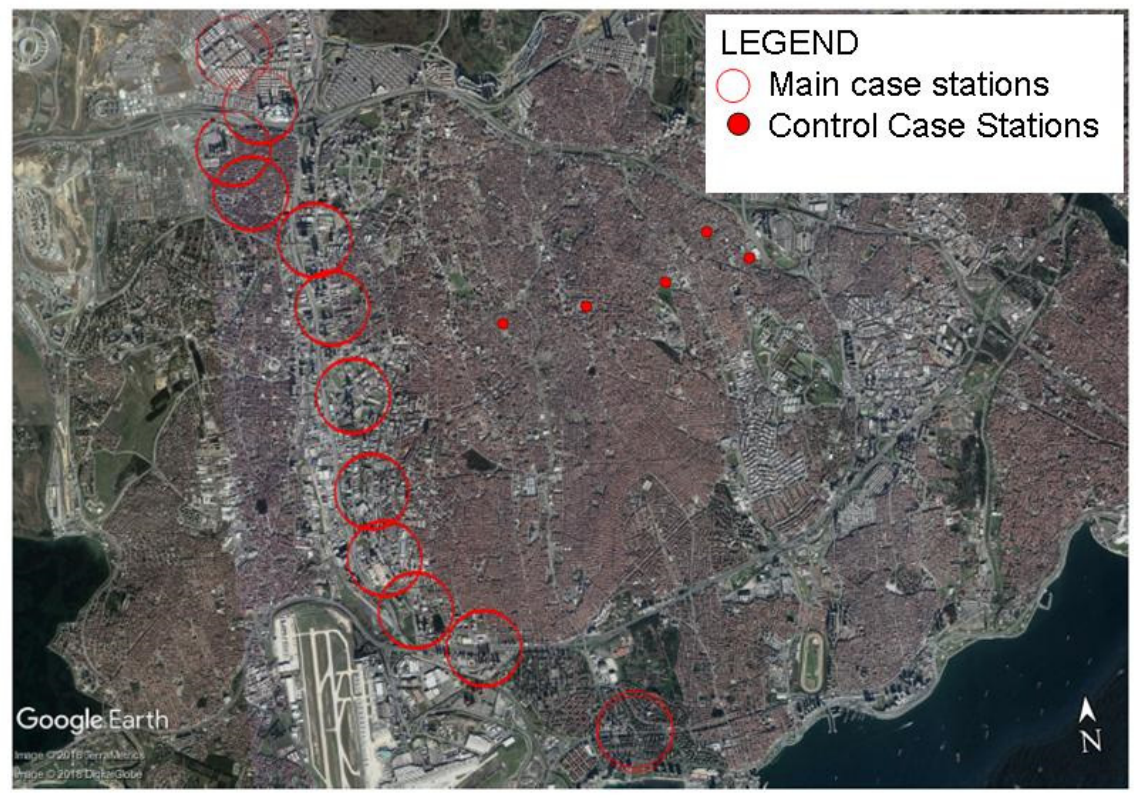

Figure 2: Two case studies together. 
In order to calculate the value impact of proximity to railway stations a questionnaire survey is conducted with rail estate agents working around the stations. Details on housing prices and their attributes are collected in the second railway corridor which has 5 stations. Around those 5 stations in the control case, 653 questionnaires are collected in total. After the model is developed the impact of proximity to a railway station is calculated and used for the main case study.

\subsection{Questionnaire study}

In order to collect real estate data, a questionnaire was prepared, and with the help of the questions below the attributes of each housing unit was collected from real estate agents.

In this part of the study, the first area is modeled by using the Hedonic Pricing model. The impact of each and every attribute on the housing price is calculated using the 665 questionnaires. As there is a metro corridor in this area the distance of the housing units to the station is within a reasonable walking distance. The study continues with detailed discussions on the first model. The method of calculating distance: Google Earth program is used to calculate distance. Not air distance but walking distance is taken into account.

\section{MODEL RESULTS}

742 questionnaires are needed to remain within the $95 \%$ confidence interval with a $10 \%$ error margin $\mathrm{N}=1.962 *$ var $/ 0.10 *$ mean

However, the number of the questionnaires obtained for this area from real estate agents was 653.

To begin with, according to the calculated t-test values asserted above, almost all the explanatory variables exhibit statistically significant coefficients, except for X9 (west or not) and X10 (north or not). Secondly, according to the calculated F-test, as a unity the model is statistically significant. In other words, the theoretical investigation which refers to the Hedonic Pricing model of the related housing units seems statistically meaningful. Thirdly, according to calculation of the coefficient of determination $\left(\mathrm{R}^{\wedge} 2\right)$, that is equal to 0.5655 , is a kind of acceptable value for such an explanatory investigation, asserting that the stated independent variables; in modeling housing prices, are able to statistically explain the related price changes around $56.55 \%$ level.

Table 4: Questionnaire.

\begin{tabular}{|cl|}
\hline HOUSE CODE \\
\hline 1. & Distance to Metro station \\
\hline 2. & Floor area of the building \\
\hline 3. & Building Facade \\
\hline 4. & Price of property \\
\hline 5. & Age of Building \\
\hline 6. & Size of building \\
\hline 7. & Number of Rooms \\
\hline 8. & Number of Bathrooms \\
\hline 9. & Existence of Alaturka Toilette \\
\hline 10. & Existence of Elevator \\
\hline
\end{tabular}


Table 5: Model Results.

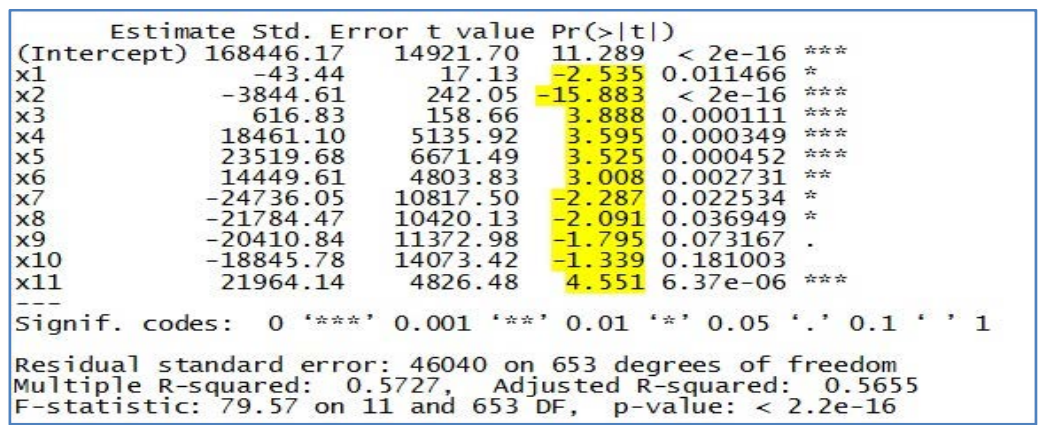

Characteristics used to develop the model are:

$\mathbf{X 1} 1=$ distance; $\mathbf{X 2}=$ age of building; $\mathbf{X 3}=$ size of the housing unit; $\mathbf{X} \mathbf{4}=$ number of rooms; $\mathbf{X 5}=$ number of bathrooms; $\mathbf{X} \mathbf{6}=$ existence of alaturka toilette; $\mathbf{X} \mathbf{7}=$ corner or not; $\mathbf{X 8}=$ south or not; $\mathbf{X 9}=$ west or not; $\mathbf{X 1 0}=$ north or not; $\mathbf{X 1 1}=$ Elevator existence.

The Hedonic Pricing model suggests the price function of a house in this area, which is as follows;

$\mathrm{P}=168446.17-43.44 * \mathrm{x} 1-$

$3844.61 * \mathrm{x} 2+616.83 * \mathrm{x} 3+18461.10 * \mathrm{x} 4+23519.68 * \mathrm{x} 5+14449.61 * \mathrm{x} 6-24736.05 * \mathrm{x} 7-$

$21784.47 * x 8-20410.84 * x 9-18845.78 * x 10+21964.14 * x 11$

In the second part of the study, model results calculated by using data in the second railway corridor called Esenler- Kirazlı Metro Line is used to calculate the expected price of the main case study area called Ataköy-Basın Ekspres-İkitelli Metro Corridor after the metro project is completed. By using coefficients derived from the first Hedonic Pricing model, the prices of 1151 housing units are estimated. 493 housing unit out of 1151 are estimated to have increased in value, the other 662 are estimated to have decreased in value. The reason for this decrease is discussed during the discussion part of this study. According to the results the value increase ratio among 493 housing units is calculated as $31 \%$. This study proves that once the metro project is completed, there will be a total value increase of 33 million Turkish Lira.

\section{CONCLUSION}

The results of the first model are applied to the second study in order to calculate the increase in property values after completion of the metro project. However, the model forecast showed that the value of the 662 housing units is not likely to increase but will decrease. The reason behind this phenomenon is the characteristics of the chosen case study areas. Even if those areas are chosen based on different criteria, each part of a city creates its own value. The two areas in question are located close to each other but have different dynamics; housing prices are very high in the second area, thus the model estimated the price after the rail connection is less than the actual price. This also shows that housing prices in this area are exaggerated. The Model estimates that a housing unit with 2 rooms and $78 \mathrm{~m}^{2}$ has a value of $259.000 \mathrm{TL}$ after the rail connection, whereas the price quoted by the real estate agents for the property before the rail connection is $420.000 \mathrm{TL}$. This value will eventually increase. Instead of individual based stated prices direct manipulative purchasing price declared by local real estate agencies had been gathered, thus probability of aggregation errors with regards to the indicated prices would have caused a certain degree of bias in the models. 


\section{DISCUSSION}

For further studies, firstly, the first model should be calibrated to establish meaningful coefficients and the model should be used again for the second study area to obtain real value increases. Secondly, as proven in literature, metro projects tend to increase land values and property values. As a next step of this study, ways to internalize this value increase should be investigated, for instance a new tax regulation on property value increase that applies to the owners could be introduced in order to use the income for the financing of rail projects. Another step of this study should be the collection and redistribution mechanism of these taxes and the legal background thereof.

\section{REFERENCES}

[1] Özgür, Ö., An analysis of rail transit investments in Turkey: Are the expectations met? 2009.

[2] Jain, P., Avenues for transport infrastructure finance in Hong Kong: Public-private financing initiatives, 2002.

[3] Yankaya, U. \& Çelik, M., Kamu Ulaşım Yatırımlarının Gayrimenkul Değerleri Üzerine Etkisinin Modellenmesi: İzmir Metrosu Örneği, 2013.

[4] Salon, D. Opportunities for value capture to fund public transport: A comprehensive review of the literature with a focus on East Asia, 2011.

[5] Nakagava \& Matsunaka, Transport Policy and Funding, 2006.

[6] Avrasya Tüneli. Online. www.avrasyatuneli.com/. Accessed on: 22 Jan. 2017.

[7] Online. www.istanbulunmetrosu.com/Haritalar?Kod=1. Accessed on: 18 Jul. 2018.

[8] Banister, D., Sustainable Mobility Paradigm, 2007.

[9] Herath, S. \& Maier, G., The hedonic price method in real estate and housing market research. 